\title{
Pelatihan Penerapan Alat Pendeteksi Bencana Banjir Dengan Teknologi Nirkabel Di Perumahan Timur Indah Residence 2 Kota Bengkulu
}

\author{
Hendy Santosa ${ }^{1}$, Junas Haidi ${ }^{2}$, Alex Surapati ${ }^{3}$ \\ ${ }^{123}$ Program Studi Teknik Elektro Fakultas Teknik Universitas Bengkulu \\ E-mail: hendysantosa@unib.ac.id
}

Article History:
Received: Oktober
2020
Revised:Desember
2020
Accepted:Juni 2021
Available online: Juni
2021

\section{Kata Kunci:}

bencana alam, banjir, deteksi dini banjir, perumahan timur indah residence 2

\begin{abstract}
Abstrak:
Bencana alam berdampak pada kehidupan sosial baik dari segi korban maupun kerugian materil. Indonesia memiliki tingkat kejadian bencana alam yang tinggi seperti gempa bumi, banjir, tanah longsor, tsunami, dll. Khususnya di Kota Bengkulu, bencana banjir sering terjadi. Kurangnya pemahaman tentang banjir menyebabkan banyak kerugian materil. Apalagi diperparah dengan minimnya alat yang bisa memberi tahu lebih dini jika akan terjadi banjir masih kurangnya peralatan peringatan dini banjir yang terpasang di Kota Bengkulu. Oleh karena itu penyuluhan tentang penyebab dan dampak yang ditimbulkan oleh banjir perlu diberikan serta pelatihan penerapan alat deteksi dini banjir lebih lanjut perlu diajarkan yang kemudian dapat dipasang di lingkungan tempat tinggal warga. Kegiatan ini telah dilaksanakan di Perumahan Timur Indah Residence 2 Kota Bengkulu bersama warga. Hasil evaluasi menunjukkan adanya peningkatan pengetahuan masyarakat tentang penyebab dan dampak banjir serta cara penanggulangannya dan khususnya pengujian alat deteksi dini banjir agar berjalan normal dan dapat memberikan peringatan kepada warga sekitar. Sehingga saat musim hujan tidak ada lagi rumah yang terkena banjir.
\end{abstract}




\section{Pendahuluan}

Perumahan Timur Indah Residence 2, Kelurahan Timur Indah, Kecamatan Gading Cempaka, Kota Bengkulu adalah perumahan rakyat bersubsidi untuk masyarakat yang berpenghasilan rendah dengan jumlah kepala keluarga sekitar 85 kepala keluarga dan secara administrasi masih bergabung dengan Rukun Tetangga (RT) 21. Perumahan tersebut mulai di huni sejak tahun 2016 dan perekonomian rata - rata masyarakat di perumahan tersebut termasuk menengah ke bawah. Karena masyarakat penghuni perumahan semuanya adalah pendatang jadi adat dan budaya serta agamanya juga berbeda - beda. Dilihat dari segi pendidikan juga berbeda - beda mulai dari SD sampai lulus S2. Dilihat dari pekerjaan masyarakat yang tinggal di perumahan tersebut juga bervariasi mulai dari pedagang, pegawai swasta, pegawai negeri, sopir dan lain - lain.

Perumahan Timur Indah Residence 2 terletak di dataran rendah dekat dengan rawa - rawa dan bendungan hulu dendam tak sudah. Di bendungan tersebut jika hujan deras tidak dapat menampung air yang datang sehingga air meluap kemudian menyebabkan banjir di sekitar perumahan. Banjir tersebut dapat ditanggulangi jika pintu air dibuka sebelum air di bendungan meluap, akan tetapi luapan air sering terjadi pada malam dan dini hari sehingga masyarakat yang ada di sekitar bendungan telah terlelap tidur. Berdasarkan seringnya musibah banjir yang dialami warga maka dibutuhkan solusi untuk mengurangi bencana banjir tersebut. Berdasarkan hal ini kami mengajukan proposal kepada LPPM untuk bisa membantu masyarakat yang tinggal di perumahan bersubsidi tersebut melalui program pengabdian kepada masyarakat skim penerapan ipteks.

Adapun pengabdian yang kami tawarkan adalah pelatihan penerapan alat pendeteksi bencana banjir dengan teknologi nirkabel (Purkovic et al., 2019; Wan Hassan et al., 2019). Alat ini dapat memberikan peringatan melalui sirine yang diletakkan di tengah perumahan jika air di bendungan telah mencapai level siaga dan bahaya maka sirine akan berbunyi. Pelatihan ini berfungsi untuk meningkatkan SDM masyarakat dibidang teknologi modern dan alat hasil pelatihan dapat dipasang dibendungan dan di perumahan. Sehingga masyarakat bisa menjaga alat pendeteksi bencana yang telah dibuat 
dan dipasang dilokasi. Karena alat ini menggunakan teknologi yang canggih gabungan dari sistem elektronika dan telekomunikasi, komunikasi dari alat pengirim dengan penerima menggunakan frekuensi sehingga alat ini bisa dipasang secara praktis dan ekonomis (Anand, 2018).

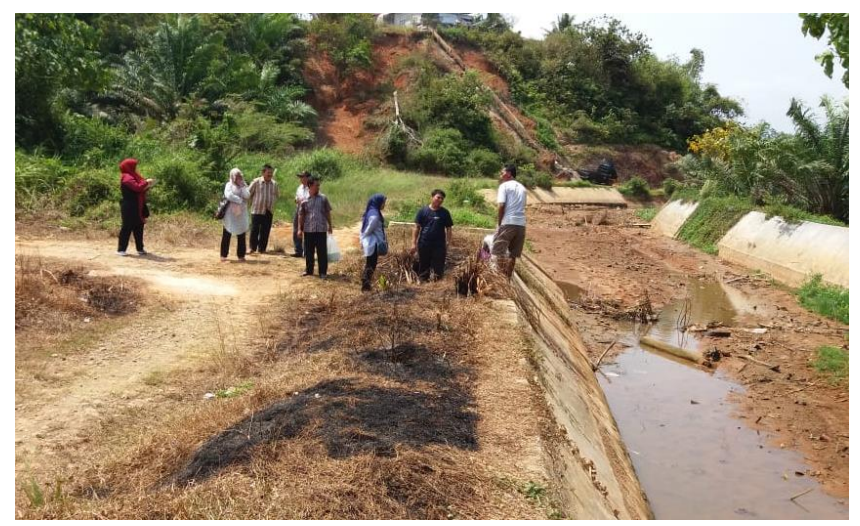

Gambar 1. Survey lapangan

\section{Metode}

Pengabdian dilaksanakan di perumahan timur indah residence 2 Kota Bengkulu. Waktu implementasi dilaksanakan pada tanggal 23 Nopember 2019. Jumlah peserta sebanyak 15 orang dipilih warga laki-laki dengan usia antara 15 - 64 tahun yang rumahnya berjarak 50 meter dari bendungan. Persiapan pengabdian ini melalui beberapa tahapan yaitu mulai dari melakukan survey lapangan dilakukan pada tanggal 07 September 2019 seperti terlihat pada Error! Reference source not found., mengadakan pertemuan dengan pihak ketua RT 21 dan warga, menyiapkan media untuk penyampaian materi berupa media power point dan video, belanja alat dan bahan untuk pelaksnaan kegiatan. Tahapan implementasi, pemberian materi umum tentang banjir, penyebab banjir, dampak dari banjir. Selanjutnya, pelatihan penerapan alat pendeteksi banjir yaitu pelatihan membuat program, pelatihan merancang peralatan elektronik, pelatihan membuat komunikasi antara alat transmiter dan penerima (Nur Rohman et al., 2017; Satria et al., 2017). Pelaksanaan kegiatan tersebut pada tanggal 20 September 2019 seperti terlihat pada Gambar 2. Kemudian, pelatihan pemasangan alat ke lokasi untuk disumbangkan ke masyarakat. Tahap terakhir, pelatihan perawatan alat deteksi 
banjir. Evaluasi akhir dilakukan pengetesan alat deteksi dini banjir, untuk melihat kinerja alat tersebut serta pemahaman tentang banjir. Evaluasi kegiatan dengan cara pengetesan dilapangan serta diskusi tanya jawab tentang banjir dan alat deteksi banjir.

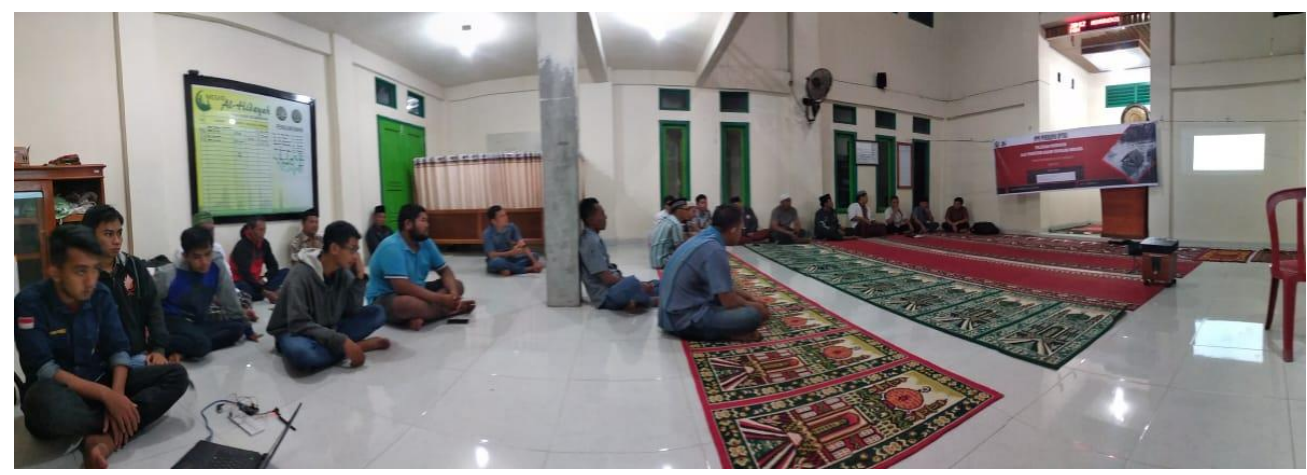

Gambar 2. Pemberian Materi Tentang Banjir dan Pelatihan Penerapan Alat Deteksi Banjir

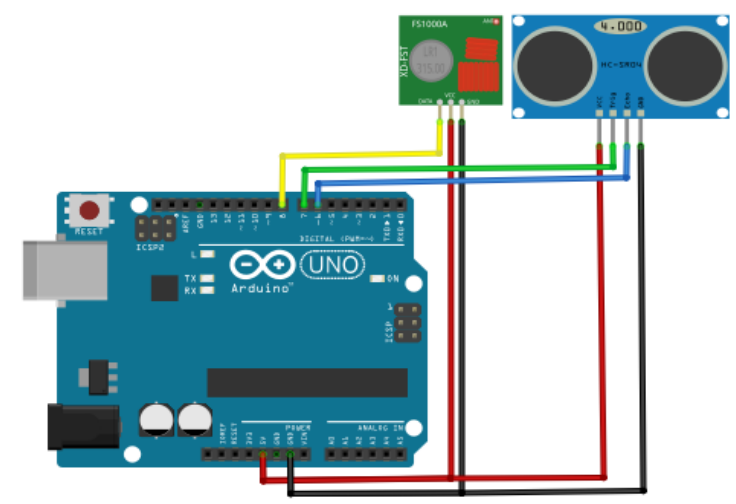

Gambar 3. Rangkaian Blok Sensor dan Pengirim di Bendungan

Adapun rangakaian alat pendeteksi banjir ini terdapat dua blok yaitu blok pengirim yang berada dibendungan sebagai pendeteksi level air (Prasetyo et al., 2015; Veronika Simbar \& Syahrin, 2017; Yuliandoko et al., 2018)dan blok kedua adalah blok penerima yang berada dipemukiman penduduk sebagai penerima informasi kondisi level air dibendungan (Di Carlo Rasi \& Janssen, 2019; Hou et al., 2018). Selanjutnya, di blok kedua ini dilengkapi lampu yang berputar dan suara bunyi alarm sebagai tanda bahwa sudah ada 
potensi terjadi banjir. Rangkaian blok satu dan rangkaian blok dua alat pendeteksi banjir dapat dilihat pada Gambar 3 dan Gambar 4.

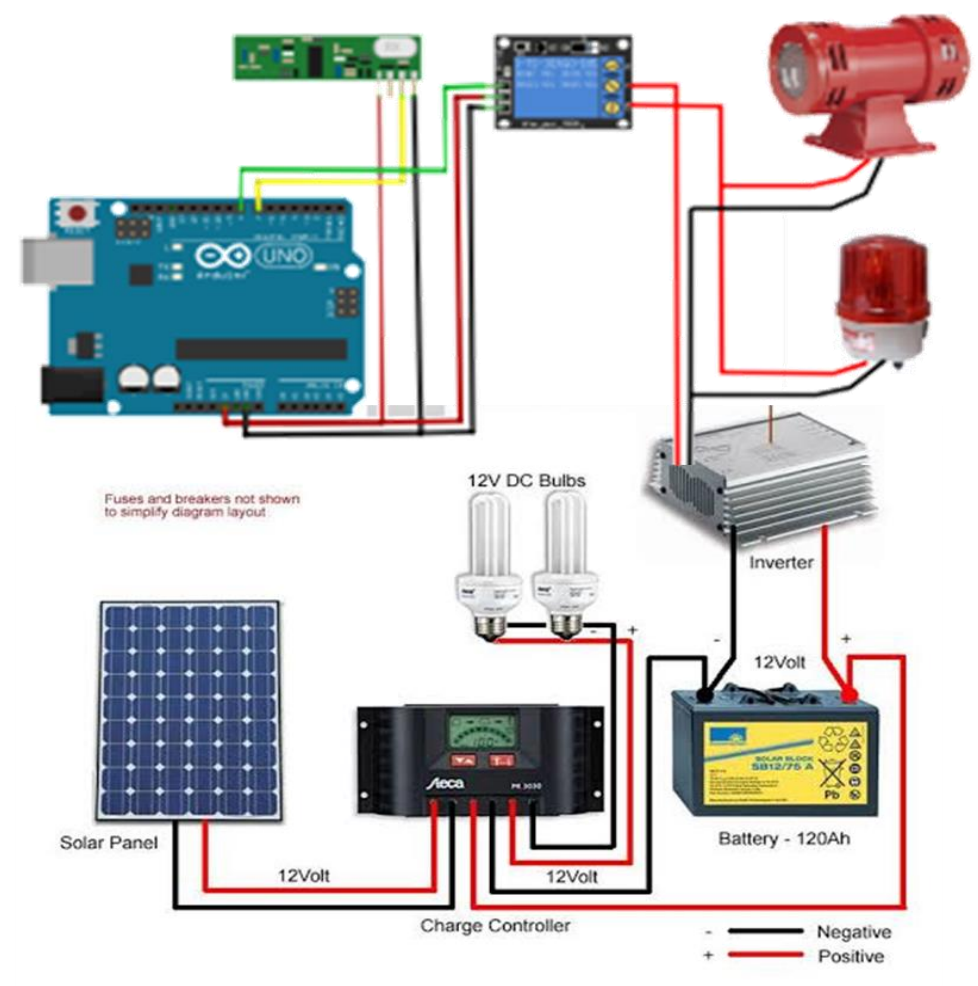

Gambar 4. Rangkaian Blok Penerima dan Analog Output Berupa Sirine dan Lampu Putar Dengan Power Supplay PLTS

\section{Hasil}

Tahap awal kegiatan pengabdian kepada masyarakat ini mempersiapkan pembelian peralatan seperti Arduino nano, sirine, solar sel, RF transmitter/receiver, baterai, sensor ping. Selain itu dilakukan survey awal untuk melihat kondisi perumahan dan bendungan. Tahap kedua adalah merancang kegiatan penyuluhan atau sosialisasi pada usia produktif yang dituju untuk pengabdian. Tahap ketiga yaitu merancang alat pendeteksi banjir yang akan digunakan untuk pelatihan pembuatan alat deteksi dini banjir. Tahap keempat adalah melakukan perakitan dan pengetesan alat untuk pelatihan yang dilakukan di Laboratorium Elektronika dan Telekomunikasi, Prodi Teknik Elektro, Fakultas Teknik Unversitas Bengkulu. 

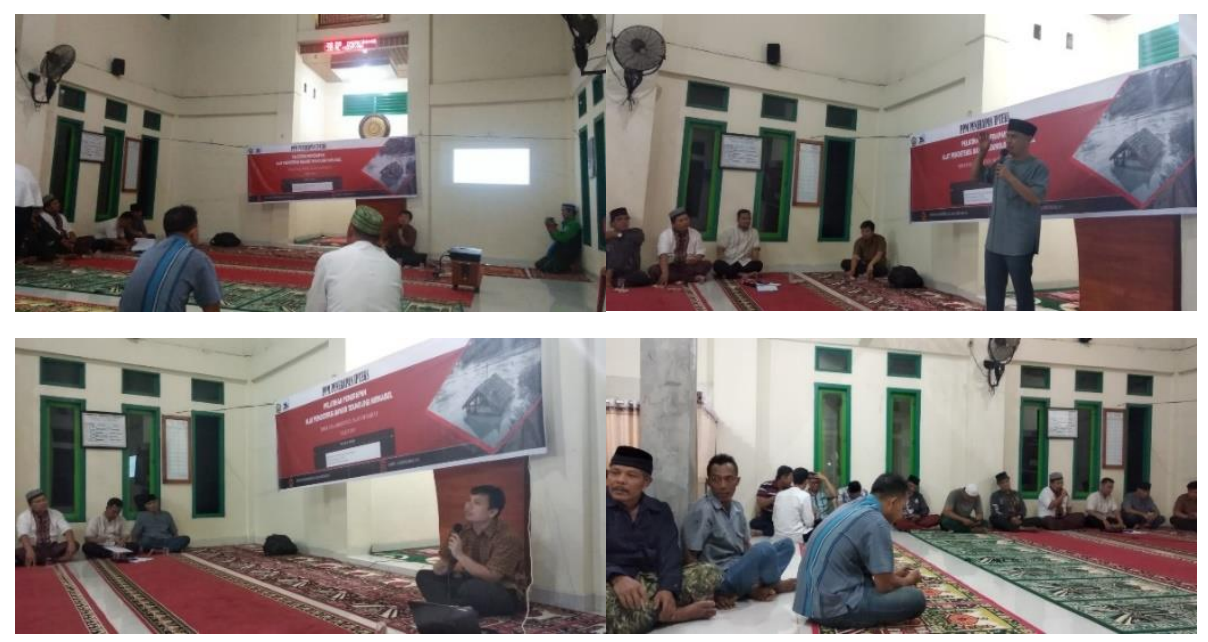

Gambar 5. Pemberian Pengetahuan Tentang Penyebab, Dampak, Penanggulangan Serta Penerapan Alat Deteksi Banjir
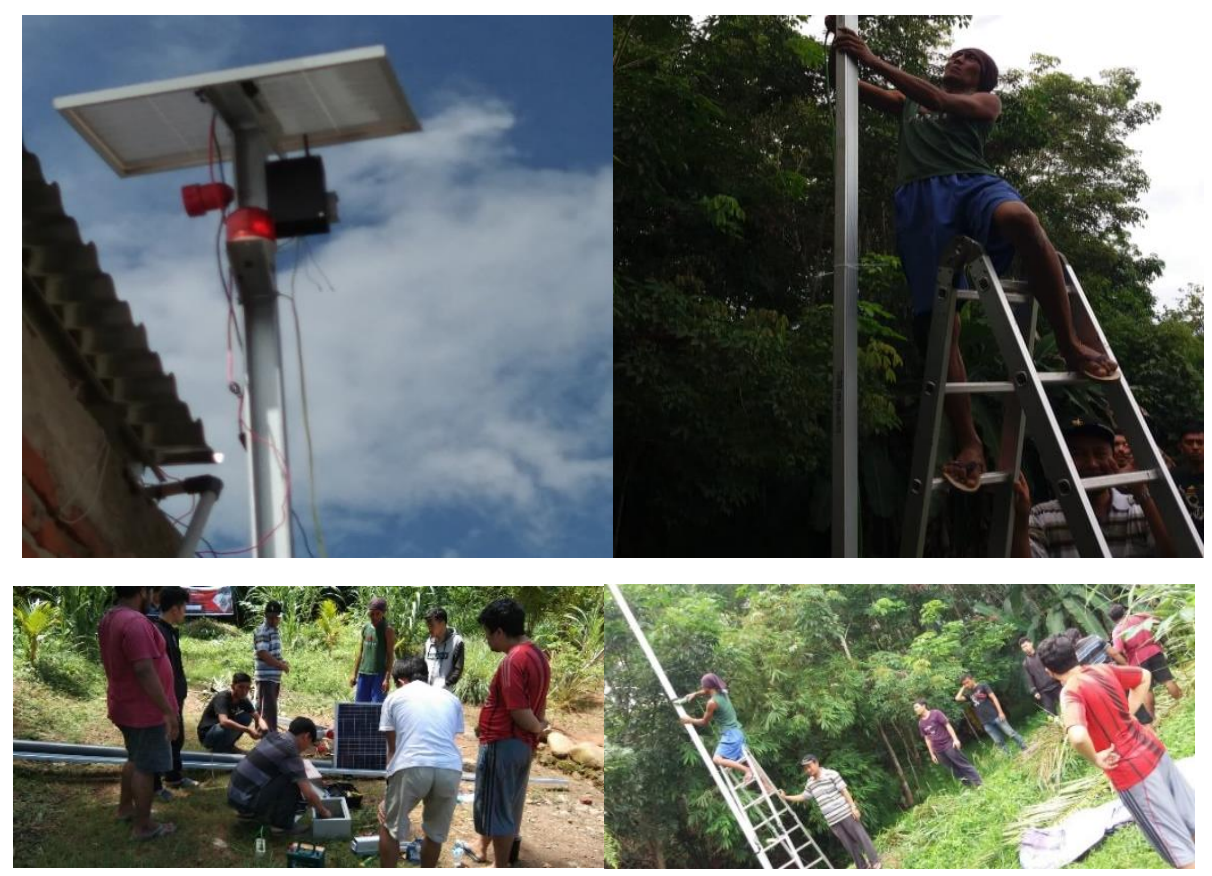

Gambar 6. Pemasangan Alat Deteksi Dini Banjir

Tahap kelima yang sudah dilaksanakan juga yaitu mengurus ijin kepada pihak terkait untuk teknik pelaksanaan penyuluhan dan pelatihan di 
perumahan timur indah residence 2. Tahap keenam telah dilakukan penyuluhan atau sosialisasi penyebab dan dampak dari banjir. Tahap ketujuh telah dilakukan pelatihan penerapan alat deteksi dini untuk banjir kepada 15 warga laki-laki usia produktif 15 - 64 tahun seperti yang terlihat pada Gambar 5. Tahap kedelapan telah dilakukan pemasangan alat di sungai sebagai pendeteksi air mengalami peningkatan dan dikirikan ke rumah salah satu warga (Ketua RT 21) sebagai penerima sinyal peringatan yang kemudian di pencarkan menggunakan sirine seperti terlihat pada Gambar 6. Tahap terakhir telah dibuat jurnal pengabdian dan laporan akhir pengabdian. Diagram alir kegiatan dapat dilihat

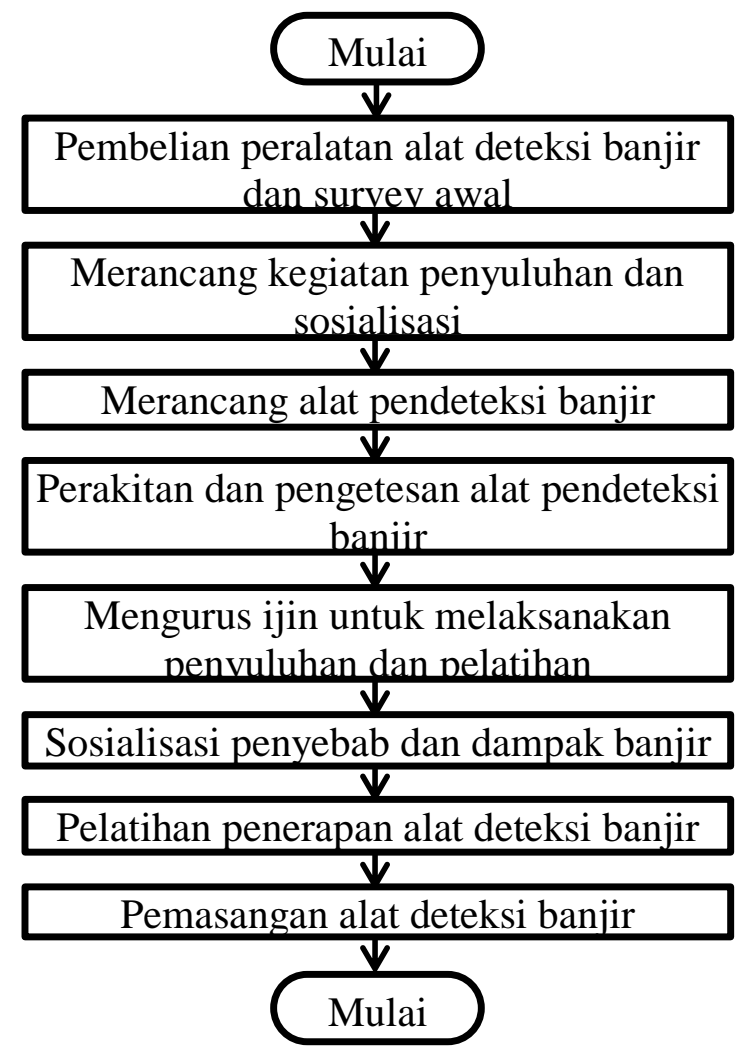

Gambar 7. Diagram Alir Kegiatan Pengabdian Kepada Masyarakat

\section{Diskusi}

Evaluasi akhir dilakukan 1 minggu setelah penerapan, untuk melihat 
keberhasilan kegiatan ini. Evaluasi kegiatan dengan memberikan diskusi pertanyaan kepada warga yang telah mengikuti kegiatan implementasi sebelumnya. Hasil evaluasi mengalami peningkatan pengetahuan peserta bisa menerangkan tentang banjir serta bagaimana melakukan perawatan terhadap alat deteksi dini banjir. Dari 15 warga yang mengikuti pelatihan terdapat $67 \%$ (10 orang) yang paham dan $33 \%$ (5 orang) yang cukup paham. Hal tersebut dapat disimpulkan bahwa pelatihan yang diadakan berhasil dikarenakan tidak ada warga yang tidak paham ataupun kurang paham mengenai banjir dan penerapan alat deteksi banjir. Hasilnya dapat dilihat pada Gambar 8. Sedangkan serah terima alat deteksi banjir kepada ketua RT 21 seperti yang terlihat pada Gambar 9.

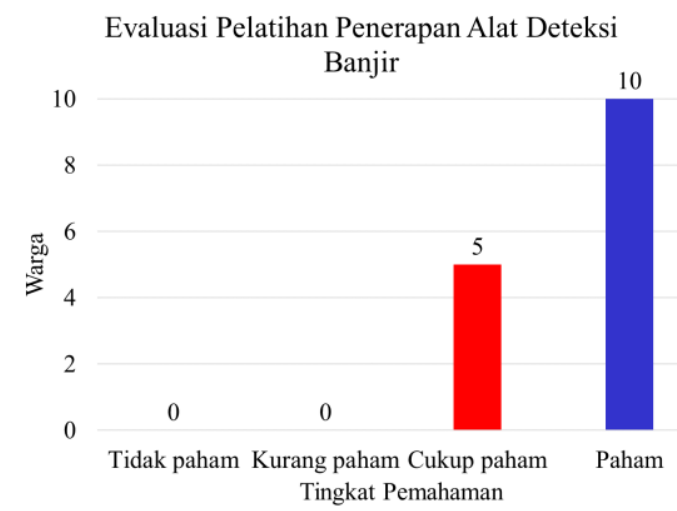

Gambar 8. Hasil Evaluasi Pelatihan Penerapan Alat Deteksi Banjir.

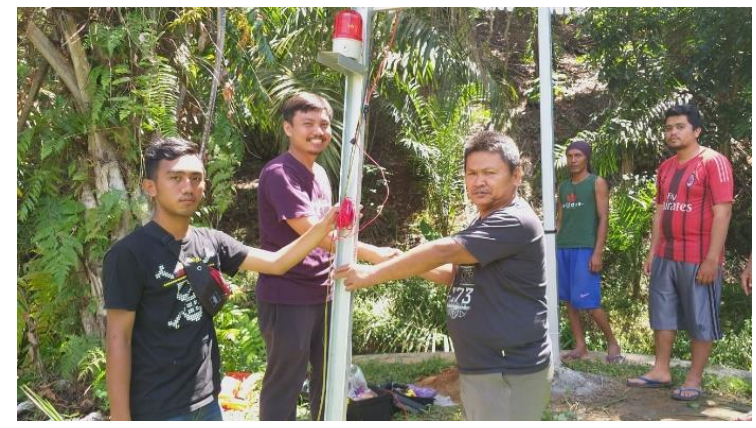

Gambar 9. Penyerahan Alat Deteksi Dini Banjir

\section{Kesimpulan}


Berdasarkan kegiatan pengabdian yang telah dilaksanakan, maka dapat disimpulkan hal-hal sebagai berikut:

1. Warga perumahan Timur Indah Residence 2 memperoleh tambahan pengetahuan tentang penyebab, dampak, penanggulangan serta penerapan alat deteksi dini banjir.

2. Warga perumahan Timur Indah Residence 2 dapat pengetahuan tentang perawat alat pendeteksi dini banjir.

3. Hasil evaluasi menunjukkan bahwa $67 \%$ warga paham dan $33 \%$ cukup paham serta tidak ada warga yang tidak paham atupun kurang paham.

\section{Pengakuan/Acknowledgements}

Ucapan terima kasih kepada masyarakat di perumahan Timur Indah Residence 2 Kota Bengkulu dan khususnya kepada bapak Ketua RT 21 yang telah membantu terlaksananya kegiatan ini serta Lembaga Penelitian dan Pengabdian Kepada Masyarakat (LPPM) Univesitas Bengkulu yang telah mendanai pengabdian tersebut.

\section{Daftar Referensi}

Anand, S. (2018). An integrated subsystem for basement flood detection. International Journal of Advance Research, Ideas and Innovations in Technology, 4(4), 204-207.

Di Carlo Rasi, D., \& Janssen, R. A. J. (2019). Advances in Solution-Processed Multijunction Organic Solar Cells. Advanced Materials, 31(10). https://doi.org/10.1002/adma.201806499

Hou, Q., Bacal, D., Jumabekov, A. N., Li, W., Wang, Z., Lin, X., Ng, S. H., Tan, B., Bao, Q., Chesman, A. S. R., Cheng, Y. B., \& Bach, U. (2018). Back-contact perovskite solar cells with honeycomb-like charge collecting electrodes. Nano Energy, 50, 710-716. https://doi.org/10.1016/j.nanoen.2018.06.006

Nur Rohman, F. S., Fikri, A. A., Fuad, A. nur, Rohim, R., \& Firmansyah, R. (2017). Telemetri Flowmeter Menggunakan RF Modul 433MHz. Journal of Electrical and Electronic Engineering-UMSIDA, 1(1), 8. https://doi.org/10.21070/jeee-u.v1i1.9

Prasetyo, J., Purwanto, \& Rahmadwati. (2015). Uji Performansi Pada Sistem Kontrol Level Air Dengan Variasi Beban MENGGUNAKAN 
KONTROLER PID. Jurnal Mahasiswa TEUB, 3(17).

Purkovic, D., Coates, L., Honsch, M., Lumbeck, D., \& Schmidt, F. (2019).

Smart river monitoring and early flood detection system in Japan developed with the EnOcean long range sensor technology. 2019 2nd International Colloquium on Smart Grid Metrology, SMAGRIMET 2019

- Proceedings. https://doi.org/10.23919/SMAGRIMET.2019.8720390

Satria, D., Yana, S., Munadi, R., \& Syahreza, S. (2017). Prototype of Google Maps-Based Flood Monitoring System Using Arduino and GSM Module. International Research Journal of Engineering and Technology, 4(10), 1044-1047. www.irjet.net

Veronika Simbar, R. S., \& Syahrin, A. (2017). Prototype Sistem Monitoring Temperatur Menggunakan Arduino Uno R3 Dengan Komunikasi Wireless. Jurnal Teknik Mesin, 5(4), 48. https://doi.org/10.22441/jtm.v5i4.1225

Wan Hassan, W. H., Jidin, A. Z., Aziz, S. A. C., \& Rahim, N. (2019). Flood disaster indicator of water level monitoring system. International Journal of Electrical and Computer Engineering, 9(3), 1694-1699. https://doi.org/10.11591/ijece.v9i3.pp1694-1699

Yuliandoko, H., Subono, Wardhany, V. A., Pramono, S. H., \& Siwindarto, P. (2018). Design of flood detection system based on velocity and water level sensor in Arduino with SWOD application on Kalimati-Kretek Gantung DAM Banyuwangi. IOP Conference Series: Materials Science and Engineering, 403(1). https://doi.org/10.1088/1757899X/403/1/012066 